\title{
Indirect fluorescent antibody technique in the serology of Toxoplasma gondii
}

\author{
S. FLETCHER \\ From the University Department of Pathology, Western Infirmary, Glasgow
}

SYNOPSIS The indirect fluorescent antibody technique has been used to titrate patients' antibody against Toxoplasma gondii. Rigorous tests of the immunological validity of the method were made. The reactions of the gamma globulin of human immune serum with Toxoplasma gondii and fluorescent rabbit anti-human gamma globulin were thus shown to be specific. Thereafter the technique could be used with confidence to detect the reaction between doubling dilutions of patient's serum and smears of unfixed Toxoplasma gondii. In this way, titres were obtained with the indirect fluorescent antibody technique which agreed well with those of the dye test at both low and high levels of antibody.

Compared with the dye test, the indirect fluorescent antibody technique has many advantages. The end-point is sharp and obviates the counting of stained and unstained organisms; supplies of antibody-free accessory factor sera are not needed; prozones undetected by the dye test are strongly positive at screening dilutions, the reagents keep indefinitely and lend themselves to preparation, standardization, and issue by a central reference laboratory.

Serological confirmation of Toxoplasma gondii infection is commonly provided by the cytoplasmmodifying (dye) test of Sabin and Feldman (1948) and by the complement-fixation test of Warren and Sabin (1942) as subsequently modified by Sabin (1949). The more important dye test is based on a rather unusual immunological phenomenon, namely, that toxoplasmata whose cytoplasm has been modified by exposure to specific antibody fail to stain with alkaline methylene blue. The dye test is a difficult technique to carry out. Constant intraperitoneal passage of Toxoplasma gondii in mice is required and the living organisms must be used almost immediately after collection. The end-point of the titration is obtained by a laborious count of unstained and stained toxoplasma. An additional disadvantage is that the reaction proceeds only in the presence of a serum accessory factor which must be supplied by fresh antibody-free human serum. Such accessory factor sera may only be obtained after screening perhaps as many as 100 donors. Even taking all the precautions derived from the experiences of Beverley and Beattie (1952) there still seem to be uncontrollable influences which make its performance more difficult. Thus Frenckel, in the discussion of Eichenwald's contribution (1956), Received for publication 6 May 1964. records the prevalence of false positive reactions due to modification of the toxoplasma by antibody derived from the mice in which they are passaged. $\mathrm{He}$ emphasizes the frequency of prozones, discourages 'screening' at low serum dilutions, and urges a complete titration by doubling dilutions to beyond 1 in 1,024 in all cases. Frenckel also quotes Jacobs and Cook (1954) who observed that patient's antibody may be blocked by soluble antigen in the toxoplasma exudate and thus lead to false negative results.

In view of the difficulties of the dye test it is understandable that only a few laboratories offer it as a diagnostic service. Although it is a very sensitive test, it is sometimes thought to lack specificity. Its titres rise early in acute infection, reach numerically high values, e.g., 1 in 4,096, and decline slowly.

The complement-fixation test, on the other hand, is thought to be highly specific but it is much less sensitive. It rises late in the infection, reaches numerically low titres, e.g., 1 in 128 , and declines rapidly. It is thus sometimes taken as evidence of acute infection. Recently it has been discontinued by the reference laboratories and now only the dye test titres are reported.

There is thus apparently much to be said in favour of Ludlam's (1960) observation that there is a need 
for 'a serological test as sensitive as the dye test but less exacting'.

In this paper, I present evidence that the indirect fluorescent antibody test may well fill the need. Smears of Toxoplasma gondii are incubated with serial dilutions of patient's serum. After adequate washing to remove unreacted serum components, specific reaction may be detected up to titre by applying fluorescein-conjugated anti-human gamma globulin. On dark-ground ultra-violet microscopy, the toxoplasma fluoresce in the green with an intensity determined by the amount of patient's antibody which was available to react with them. Previous workers have applied this principle to toxoplasma serology. Thus, Kelen, Ayllon-Leindl, and Labzoffsky (1962) found that titres with the indirect fluorescent antibody test closely paralleled those of the complement-fixation test and were of the same numerical order. Mandras, Vanini, and Ciarlini (1962), on the other hand, found higher values for these titres which were approximately comparable with those of the dye test.

There is much in favour of retaining serological titres which are of the same order as the dye test and thus familiar to clinicians. I therefore considered that the aim of this work must be to obtain titres with the indirect fluorescent antibody test as close as possible to those of the dye test without jeopardizing strict immunological validity. Accordingly, the techniques finally adopted are described and results are given of several tests which sufficiently establish the immunological specificity of the method. Thereafter a technique suitable for routine use is applied to the titration of a range of sera of known dye test titre and the results are discussed.

\section{MATERIALS AND METHODS}

ORGANISM Toxoplasma gondii (RH strain) was kept passaged in white mice of the Porton strain at three-tofour-day intervals. The peritoneal exudates so obtained were diluted five times with saline and $0.1 \mathrm{ml}$. was used to inject healthy mice intraperitoneally.

TOXOPLASMA GONDII SMEARS A washed Toxoplasma suspension was prepared from mouse peritoneal exudates by the method of Goldman (1957) but formalin fixation was omitted. As far as possible, to avoid the presence of mouse antibody, young (8-10-week-old) mice were used and their peritoneal exudates were harvested at three days (Beverley and Beattie, 1952).

From the suspension, air-dried smears not more than $1 \mathrm{~cm}$. diameter with $300-400$ toxoplasma per high-power field, were made. They were stored over $\mathrm{CaCl}_{2}$ in a desiccator at $-20^{\circ} \mathrm{C}$. The smears showed no tendency to wash off and were quite safe as the toxoplasma die rapidly. Since their antigens were undamaged by formalin, the organisms fluoresced more brilliantly than after fixation.
E. COLI PERITONEAL EXUDATES E. coli N.C.T.C. 8196 was grown in $15 \mathrm{ml}$. of broth for 24 hours. One ml. of the culture was injected intraperitoneally in each of a dozen mice. The mice were killed after 24 hours and the peritoneal exudates harvested with the help of saline flushing. The collected exudates were made up to $30 \mathrm{ml}$. with saline, spun hard, and the sediment of $E$. coli and peritoneal macrophages was stored at $-20^{\circ} \mathrm{C}$.

RAT LIVER POWDER The method of Nairn (1962) was used to prepare an acetone-dried rat liver powder. Haemoglobin was removed by thorough washing with several large volumes of cold saline. When the powder was still damp from its final acetone wash it was removed from the filter paper and thoroughly rubbed with the fingers. In this way the material dried as a fine light powder of good activity in relation to its weight, and grinding in the mortar was avoided.

HUMAN SERA AND SERUM PRODUCTS Sera of known dye test titre, normal sera, and sera with antibody titres against a variety of heterologous antigens were obtained and stored at $-20^{\circ} \mathrm{C}$. until used.

One serum with a dye test titre of 1 in 4,096 was used as a reference standard throughout the work.

Human gamma globulin (as supplied for measles prophylaxis) and human serum albumin (freeze dried) were obtained from the Blood Transfusion Service and stored at $4^{\circ} \mathrm{C}$. until used.

PREPARATION OF HUMAN GAMMA GLOBUlin Human serum, $10 \mathrm{ml}$., was diluted to $100 \mathrm{ml}$. with $0.02 \mathrm{M}$ phosphate buffer, $p \mathrm{H} 6 \cdot 3$, and made into a slurry with $10 \mathrm{~g}$. of DEAE Sephadex A-50 (Pharmacia, Uppsala) previously equilibrated with the same buffer according to the makers' instructions. The mixture was stirred overnight at $4^{\circ} \mathrm{C}$. and then centrifuged. The supernatant which contained the gamma globulin fraction was removed and concentrated at $4^{\circ} \mathrm{C}$. by pressure dialysis against saline. A Visking membrane of $24 / 32$ in. diameter operated at $80 \mathrm{~cm}$. $\mathrm{Hg}$ was used and pressure was maintained until the volume was approximately $2 \mathrm{ml}$. A typical total yield (estimated spectrophotometrically at $280 \mathrm{~m} \mu$ ) was $150 \mathrm{mg}$ of gamma globulin. The purity of the preparation was checked by immuno-electrophoresis on agar gel against a trough of rabbit anti-whole human serum.

IMMUNIZATION OF RABBITS WITH HUMAN GAMMA GLOBULIN Rabbits were immunized with gamma globulinFreund's complete adjuvant mixture by two $1.5 \mathrm{ml}$. injections one week apart. After five weeks a booster of $2 \mathrm{ml}$. was given and after 10 days the indirect Coombs test (Boorman and Dodds, 1957) was performed on the rabbit serum. If the titre was unsatisfactory, a boost with $1 \mathrm{ml}$. of an alum-absorbed vaccine prepared from Blood Transfusion Service gamma globulin after the method of Proom (1943) was used. Gamma globulin, $750 \mathrm{mg}$., was substituted for the $25 \mathrm{ml}$. of serum quoted in the original method. The rabbit antiserum obtained after boosting had an anti-human gamma globulin titre of 1 in 128,000 + in the indirect Coombs test. 
CONJUGATION OF RABBIT IMMUNE GLOBULIN From the rabbit anti-human gamma globulin serum just described, a preparation of immune gamma globulin was obtained using the DEAE Sephadex A-50 method described above. The final yield after pressure dialysis was $185 \mathrm{mg}$. in a volume of $2.5 \mathrm{ml}$.

Conjugation was carried out as described by Nairn (1962). Rabbit gamma globulin was diluted to a level of approximately $10 \mathrm{mg}$. per $\mathrm{ml}$. with the recommended pH 9.0 buffer.

To avoid large amounts of unreacted fluorescent material fluorescein iso-thiocyanate was used at a concentration of only $20 \mathrm{mg}$. per gram of gamma globulin. Before use each $2 \mathrm{mg}$. required was dissolved in $1 \mathrm{ml}$. of acetone.

When conjugation was over unreacted fluorescent material was removed on a Sephadex G-50 column prepared according to Nairn (1962) and the manufacturer's literature. The conjugated gamma globulin was eluted by the recommended buffer and concentrated by pressure dialysis to a final volume of $3 \mathrm{ml}$. The material was stored at $-20^{\circ} \mathrm{C}$. in $0.5 \mathrm{ml}$. lots and used at dilutions between $1 / 20$ and $1 / 35$ according to the needs of particular experiments.

NON-SPECIFIC STAINING At the dilutions used for various applications non-specific staining was minimal, but, as an extra precaution, all conjugates were treated for one hour at $4^{\circ} \mathrm{C}$. with previously moistened rat liver powder in the proportion of one small knife point of powder per 30 drops of diluted conjugate.

TITRATION OF PATIENT'S SERA All dilutions were made in saline by dropping methods, using the same pipette for additions of diluent and reagent. The method used for the titration of patient's sera and in the tests of immunological specificity was as follows.

1 Three or four drops of each dilution of patient's serum were applied to a separate toxoplasma smear. The slides were put in 6 in. diameter Pyrex Petri dishes along with moist cotton wool to prevent drying. Incubation at $37^{\circ} \mathrm{C}$. for 15 minutes followed.

2 The smears were momentarily rinsed under a gentle stream of tap water and then washed for 15 minutes in saline-filled Coplin jars on a shaking machine.

3 As much saline as possible was removed from around the smears with a soft cloth so that the fluorescent antibody subsequently added was not unduly diluted.

4 To the still wet smear, one large drop of diluted fluorescent conjugate was added and the smears were incubated for 15 minutes at $37^{\circ} \mathrm{C}$.

5 The smears were once more gently rinsed under the tap and immediately washed by agitation in fresh saline for 15 minutes.

6 The smears were thoroughly but gently rinsed in tap water to remove saline. The surround was carefully dried with a soft cloth and the region of the smear left to air-dry slowly. Glycerol mounting and cover glasses were found to be unnecessary and when dry the preparations were ready for microscopy.

Titration of patient's sera may be expedited in routine use by gently blotting the smears with clean blotting-paper at stages 3 and 6 instead of wiping round them with a cloth: there is no tendency for the smears to rub off.

MICROSCOPY The apparatus used for ultra-violet dark ground microscopy was essentially that of Young (1961).

\section{RESULTS}

IMMUNOLOGICAL VALIDITY OF THE INDIRECT FLUORESCENT ANTIBODY TECHNIQUE In the experiments to be described in this section, a 1 in 20 dilution of conjugate treated with rat liver powder and found to give no non-specific staining of control smears was used except where otherwise stated.

Immune nature of the reactions Two reactions must be shown to be of immune nature: 1 that between fluorescent conjugate and human immune gamma globulin (which has combined with Toxoplasma gondii); 2 that between Toxoplasma gondii and the gamma globulin of human immune serum.

The reaction between the conjugate and human immune gamma globulin which had combined with Toxoplasma was first tested by the techniques of absorption and blocking.

Specific absorption tests A 1 in 10 saline dilution of rat liver powder-absorbed conjugate was divided

TABLE I

IMMUNOLOGICAL SPECIFICITY OF THE REACTIONS BETWEEN TOXOPLASMA GONDII, HUMAN ANTISERUM, AND FLUORESCENT ANTIHUMAN GAMMA GLOBULIN

Smears of Toxoplasma Treated for 15 Minutes at $37^{\circ} \mathrm{C}$. with 1/256 Human Toxoplasma Antiseru:n

\begin{tabular}{|c|c|c|c|c|c|c|c|c|}
\hline \multicolumn{3}{|c|}{$\begin{array}{l}\text { A. Staining by Conjugate Absorbed for } \\
1 \text { Hour at } 37^{\circ} \mathrm{C} \text {. with:- }\end{array}$} & \multicolumn{3}{|c|}{$\begin{array}{l}\text { B. Staining by Conjugate of Smears } \\
\text { Blocked for } 30 \text { Minutes at } 37^{\circ} \mathrm{C} \text {. with:- }\end{array}$} & \multicolumn{3}{|c|}{$\begin{array}{l}\text { C. Staining by Conjugate of Smears } \\
\text { Treated with 1/256 Toxoplasma Antiserum } \\
\text { Absorbed with:- }\end{array}$} \\
\hline $\begin{array}{l}\text { Human Gamma } \\
\text { Globulin } \\
(12.5 \mathrm{mg} . \text { in } \\
0.1 \mathrm{ml} .)\end{array}$ & $\begin{array}{l}\text { Human Serum } \\
\text { Albumin } \\
(12.5 \mathrm{mg} . \text { in } \\
0.1 \mathrm{ml} .)\end{array}$ & $\begin{array}{l}\text { Saline } \\
(\text { Control }) \\
(0.1 \mathrm{ml} .)\end{array}$ & $\begin{array}{l}\text { Rabbit Anti- } \\
\text { human } \\
\text { Gamma } \\
\text { Globulin }(1 / 8)\end{array}$ & $\begin{array}{l}\text { Rabbit Non- } \\
\text { immune } \\
\text { Serum }(1 / 8)\end{array}$ & $\begin{array}{l}\text { Saline } \\
\text { (Control) }\end{array}$ & $\begin{array}{l}\text { Toxoplasma } \\
\text { gondii }\end{array}$ & $\begin{array}{l}\text { Escherichia } \\
\text { coli. }\end{array}$ & $\begin{array}{l}\text { Saline } \\
\text { (Control) }\end{array}$ \\
\hline- & $+t+t$ & ++++ & - & $++t$ & $++t+$ & - & $+\div+1$ & $+t+t$ \\
\hline
\end{tabular}

C. Staining by Conjugate of Smears Treated with 1/256 Toxoplasma Antiserum rbed with:- 
into three six-drop amounts and absorbed with human gamma globulin, human serum albumin, and an equivalent volume of saline. The absorbed preparations were tested for their ability to react with Toxoplasma gondii previously incubated with a 1 in 256 dilution of standard high titre patient's serum. The details of the experiment and the results are shown in Table I, section A.

Blocking tests Toxoplasma smears previously sensitized with a 1 in 256 dilution of standard serum were 'blocked' by 1 in 8 saline dilutions of unconjugated rabbit anti-human gamma globulin serum of titre 1 in 128,000 + in the indirect Coombs test and non-immune rabbit serum. The results of fluorescent microscopy after treatment with conjugate are shown in Table I, section B.

Conjugated low Coombs titre rabbit globulin Conjugates made from rabbit anti-human serum of poor Coombs titre failed to stain toxoplasma previously treated with human immune sera.

The reaction between fluorescent rabbit antihuman gamma globulin and human immune globulin has thus satisfied controlled tests of absorption and blocking and the failure of low titre conjugates to stain has been observed. It therefore seemed fair to assume that the reaction was of a true immunological nature.

The reaction between human immune serum and Toxoplasma gondii smears was next examined.

Absorption tests Ten-drop portions of diluted standard patient's serum were absorbed by the equivalent of three peritoneal exudates from mice infected with $E$. coli and Toxoplasma gondii. After centrifuging, the absorbed serum was applied to toxoplasma smears and the standard fluorescent technique was carried out. Table I, section C, shows the details of the absorptions and the results.

Sera with high heterologous titres Several human sera with high titres against a selection of heterologous viral and bacterial antigens were set up in the standard method for the titration of patient's serum. The dilutions of rat liver powder absorbed conjugate was 1 in 30 in all cases. The titres obtained are shown in Table II and are typical of those of a 'normal' population. There is no significant cross-reaction with any of the sera investigated.

Cross-reaction of patient's immune sera with different organisms This was carried out to see if a high-titre anti-toxoplasma human serum would cross-react with a number of organisms especially protozoans, some of which the donor could not reasonably have encountered. It thus sheds additional light on the specificity of the method and has an important bearing on an occasional use of the technique, the identification of Toxoplasma gondii in unfixed infected tissues.
TABLE II

TOXOPLASMA TITRES DETERMINED BY INDIRECT FLUORESCENT ANTIBODY TEST OF SERA WITH HIGH TITRES AGAINST HETEROLOGOUS ORGANISMS

\begin{tabular}{|c|c|c|c|c|}
\hline \multirow[t]{2}{*}{ Nature of Antigen } & \multicolumn{2}{|l|}{ Agent } & \multicolumn{2}{|l|}{$\begin{array}{l}\text { Toxo- } \\
\text { plasma }\end{array}$} \\
\hline & $\begin{array}{l}\text { Agglutin- } \\
\text { ation Titre }\end{array}$ & $\begin{array}{l}\text { Comple- } \\
\text { ment- } \\
\text { fixation } \\
\text { Titre }\end{array}$ & $\begin{array}{l}\text { Indirect } \\
\text { Fluorescent } \\
\text { Antibody } \\
\text { Titre }\end{array}$ & $\begin{array}{l}\text { Dye } \\
\text { Test } \\
\text { Titre }\end{array}$ \\
\hline
\end{tabular}

Virus

1 Mumps S

2 Mumps $S$

3 Mumps $\mathrm{S}$

Chickenpox

Herpes zoster

Leptospira

1 Leptospira canicola

2 Leptospira canicola

Salmonella

1 S. paratyphi B H $\quad$ H $1 / 80$

2 S. typhi $\quad$ H Nil

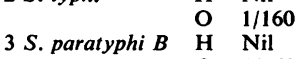

O $1 / 160$

Controls

Normal serum

Toxoplasmosis $\begin{array}{lll}\text { S. typhi } & \text { O } & 1 / 160 \\ & O & 1 / 20\end{array}$

$\begin{array}{lc}1 / 64 & 1 / 8 \\ 1 / 512 & \\ 1 / 64 & <1 / 8 \\ 1 / 512 & \\ 1 / 16 & 1 / 16 \\ 1 / 256 & \\ 1 / 128 & 1 / 8 \\ 1 / 512 & 1 / 32 \\ 1 / 512 & <1 / 8 \\ 1 / 256 & 1 / 32 \\ & \\ & 1 / 8 \\ & \\ & 1 / 8 \\ & 1 / 8\end{array}$

$<1 / 8 \quad<1 / 8$

$1 / 4096 \quad 1 / 4096$
Smears of the following classes of organisms were made:-

BACTERIA E. coli, B. subtilis, Staphylococcus aureus, Beta haemolytic Streptococcus, and Pseudomonas pyocyanea.

YEASTS Two unidentified Candida species.

PRotozoA (a) Parasitic. Trypansoma brucei, Trypanosoma congolense, Trichromonas vaginalis, Leishmania mexicana, Plasmodium gallinaceum, Toxoplasma gondii. (b) Free living. Peranema species, Paramecium species Amoeba proteus.

The smears were treated first with a 1 in 128 dilution of standard immune serum and then with a 1 in 20 dilution of absorbed conjugate.

Apart from Toxoplasma gondii, only Staphylococcus aureus and the beta haemolytic streptococcus showed bright fluorescence but E. coli, B. subtilis, and Trypanosoma congolense showed a very faint green hue. The range of organisms was then stained with a directly conjugated gamma globulin preparation from the same standard anti-toxoplasma serum and E. coli, B. subtilis, and Trypanosoma congolense now failed to stain. Thus the three organisms were considered not to have cross-reacted with Toxoplasma antibody in the indirect method. Instead they 
probably combined with immune globulin, either in the form of low titres of their appropriate antibody, or, in a non-specific fashion.

The staining of Staphylococcus aureus and beta haemolytic streptococcus by the indirect and direct techniques brought to light some interesting findings. Both organisms stained well by the indirect and direct methods. However, in the controls for the indirect method where saline was substituted for the standard anti-toxoplasma serum the beta-haemolytic streptococcus still stained although Staphylococcus aureus did not. Such findings suggest that the standard anti-toxoplasma serum contains both staphylococcal and streptococcal antibodies and that the conjugate contains streptococcal antibody in addition to that directed against human gamma globulin.

In conclusion, the absorption of the standard anti-toxoplasma serum with toxoplasma and $E$. coli and the tests of specificity with heterologous sera and heterologous organisms collectively establish the specificity of the reaction between a typical high-titre patient's serum and Toxoplasma gondii.

Since the specific nature of the reaction between conjugate and reacted human immune globulin has also been demonstrated it seemed fair to regard the overall response of the indirect fluorescent antibody technique as immunologically specific for Toxoplasma gondii.

APPLICATION OF INDIRECT FLUORESCENT ANTIBODY TECHNIQUE TO TITRATION OF PATIENT'S SERA Only when the specificity of the indirect fluorescent antibody technique had been established was its application to the titration of human anti-toxoplasma sera considered. Certain difficulties were encountered. When normal serum or very low dilutions of normal serum were used, non-specific fluorescence of the toxoplasma was found even after prolonged absorption of the conjugate with rat liver powder. Saline controls invariably showed no staining at all. Inefficient washing contributed to the effect but the most important cause was the use of absorbed conjugate in needlessly high concentration (see Nairn, 1962). The correct concentration of conjugate must therefore be found. A compromise has to be made between a concentration of conjugate high enough to detect patient's antibody with the sensitivity of the dye test, and one low enough to avoid significant fluorescence with normal serum at

TABLE III

COMPARISON OF INDIRECT FLUORESCENT ANTIBODY AND DYE TEST TITRES OF PATIENTS' SERA

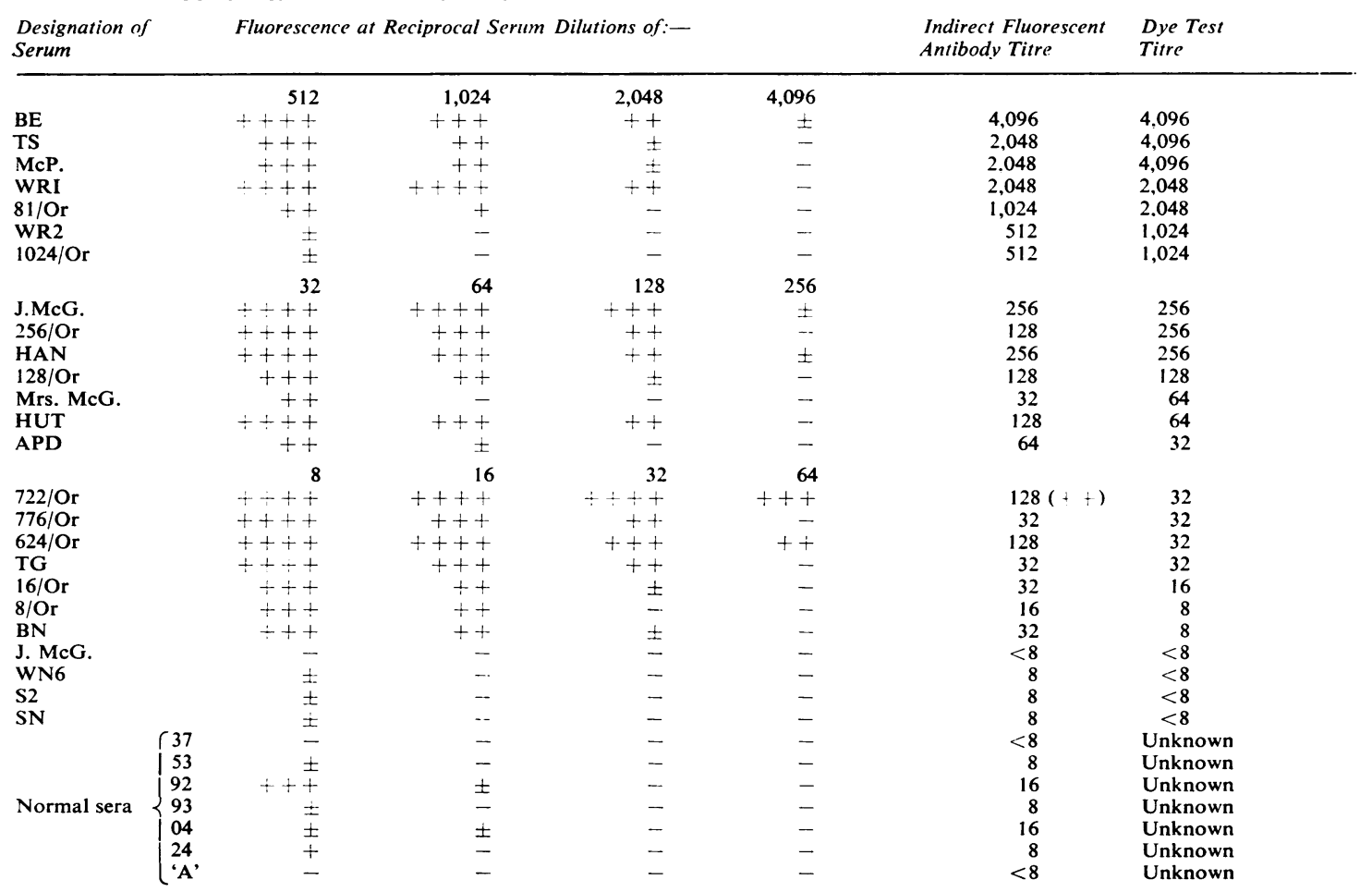


the chosen starting dilution of 1 in 8 . Accordingly, different concentrations of conjugate from 1 in 20 to 1 in 35 were made up and treated with rat liver powder. They were then applied to toxoplasma smears previously incubated with dilutions of a normal serum of negative dye test and standard serum of dye test titre 1 in 4,096. The standard procedure was rigorously followed and that concentration of conjugate was found which gave no fluorescence at 1 in 8 with the negative serum but the highest end-point with the standard positive. The latter dilution was usually equal to, or one doubling dilution lower, than the dye test titre. For the particular conjugate used throughout the work to be described, a dilution of 1 in 30 , absorbed with rat liver powder, was found to be most suitable. Every new lot of conjugate must be titrated in this way to find the optimum concentration for use in the titration of patient's sera.

When batches of patients' sera were put up for titration by the indirect fluorescent antibody technique, a few low dilutions of normal serum $(1 / 8,1 / 16,1 / 32)$ and a few limiting dilutions of standard positive serum $(1 / 1,000,1 / 2,000,1 / 4,000)$ were always included. The intensity of fluorescence was graded from ++++ to \pm and the latter was taken as the end point of the titration. The results of the titration by this technique of human sera with high, medium, low, and negative dye test titres are given in Table III.

\section{DISCUSSION}

Much of the present work has been devoted to a rigorous inspection of the specificity of each step in the technique and it is considered desirable to subject new batches of conjugate to the tests described in part 1 of the results (with the exception of those with heterologous organisms).

In order to obtain indirect fluorescent antibody technique titres approximating to those of the dye test every batch of conjugate must be titrated to find the concentration which gives the highest sensitivity with the least non-specific staining. Once this concentration has been found the routine conduct of serology by the indirect fluorescent antibody technique is very easy indeed.

Table III shows a good agreement between dye test and titres by the indirect fluorescent antibody technique. In particular, highly immune sera give by this technique titres which are equal to, or one doubling dilution less than, those of the dye test. It was with one member of this group that a most interesting observation was made. The serum designated McP. came from a youth of 18 who had a febrile illness with lymphadenopathy. Lymph node biopsy showed typical appearances of toxoplasmosis as described by Stansfeld (1961). On two occasions the titre by the indirect fluoreseent antibody technique was 1 in 2,048 and thus confirmed the clinical impression. However, the dye test was initially reported as less than 1 in 8 on routine screening up to a final dilution of 1 in 128 . In view of the clinical and histological findings and the indirect fluorescent antibody titration, I considered that the discrepant results were probably due to a prozone in the dye test. The reference laboratory very kindly repeated the dye test, this time extending the doubling dilutions to 1 in 8,192 . In this way a prozone was observed which gave negative dye test results up to a dilution of 1 in 128. At 1 in 256 the reaction was feebly positive: thereafter, it remained strongly positive up to a final titre of 1 in 4,096 which was in good agreement with the indirect fluorescent antibody technique titre of 1 in 2,048. Throughout the dilutions affected by the prozone, the indirect fluorescent antibody technique gave brilliant fluorescence. How common such sera are is not known but it seems certain that the indirect fluorescent antibody technique will detect at least some of them at low screening dilutions.

With the group of sera of only moderate dye test titre the agreement is again good and equal to, or within one doubling dilution of, the dye test titre. The lower part of Table III shows the results with sera of low dye test titre. The tendency here is for the indirect fluorescent antibody technique to read a little high-perhaps by one or even two doubling dilutions. This is illustrated clearly by the four sera of dye test titre less than 1 in 8 of which three are positive with the indirect fluorescent antibody technique.

The lowermost part of Table III shows the titres of a small group of normal individuals of unknown dye test titre. By combining the results with those of Table II for high titre heterologous sera further similarities to the dye test emerge. In the combined group of 17 sera none exceeds a dye test titre of 1 in 32 and five $(29 \%)$ are positive at 1 in 16 or over. This proportion agrees well with the common finding of reference laboratories that between 20 and $40 \%$ of normal people have dye test titres between 1 in 8 and 1 in 128 .

It is interesting to study the results of previous workers with normal and low titre human sera. Kelen et al. (1962) used the indirect fluorescent antibody technique to titrate 92 sera which were positive in the dye test at titres from 1 in 16 to 1 in 64 . Only eight were positive in the indirect fluorescent antibody technique at $\mathbf{1}$ in $\mathbf{8}$ or more, thus showing the relative insensitivity of the method. Yet another finding emphasizes the insensitivity. Normal serum 
is used as a negative control by Kelen et al. (1962) but no mention is made of diluting it. If it is, in fact, used neat some fluorescence of toxoplasma would be expected due to the prevalence of low-titre antibody. In addition, non-specific attachment of immune globulin to the toxoplasma may take place with neat serum. My experience with three different high potency conjugates was that neat normal serum nearly always gave fluorescence. The inactivation of all sera by Kelen et al. is unlikely to explain the discrepancy. The sera in the present experiments were not inactivated since early experiments showed that it had no effect on the indirect fluorescence antibody technique titres of low-titre dye test sera.

Mandras et al. (1962) followed the technique of Kelen et al. very closely but obtained a good correlation between the indirect fluorescent antibody and dye test titres especially with high-titre sera. With low-titre sera, however, the sensitivity was poor. Thus of 51 normal sera only one gave a positive reaction with the indirect fluorescent antibody technique at 1 in 10 . This is far below the expected figure.

It is difficult satisfactorily to account for the difference between the present results and those of Kelen et al. and Mandras et al. However, neither of the previous publications mentions the need to obtain toxoplasma from 8 to 10 -week-old mice killed early on the third day to avoid mouse antibody (Beverley and Beattie, 1952). Mouse antibody causes false positive reactions in the dye test but may exert a blocking effect and lead to false negatives in the indirect fluorescent antibody technique. It may thus entirely obscure the reaction with low-titre sera but diminish the titre of highly immune sera by only one or two doubling dilutions. In this way the discrepancy between the indirect fluorescent antibody technique and dye test at low titres may be explained.

A further influence operates equally at all titres and serves to decrease the sensitivity of the indirect fluorescent antibody technique as performed previously. Both groups of workers used formalin-fixed toxoplasma whose fluorescence is inferior to that of the unfixed immunologically-intact preparations used throughout the present work.

It would seem that the good agreement with the dye test which I have found depends upon the use of unfixed toxoplasma free from mouse antibody and a purified conjugate of high potency and specificity.

The indirect fluorescent antibody technique has only two disadvantages: 1 Each batch of conjugate must be tested for immunological validity. Since, however, this technique is very economical of conjugate, such tests are infrequent. 2 If animal sera are to be titrated, the appropriate species- specific conjugated gamma globulin has to be prepared. The dye test must be used as a common reference standard and the conditions of the indirect fluorescent antibody technique have to be adjusted so that comparable titres may be obtained from species to species.

On the other hand the advantages of the indirect fluorescent antibody technique are simplicity in routine use, indefinite storage of reagents, economy of mice, sharp end point, avoidance of numerical counts and accessory factor, absence of prozones permitting screening procedures, and, finally, ease of standardization.

The last point is very important indeed. Dye test results may vary greatly from one laboratory to another. This need not be so with the indirect fluorescent antibody technique. The reagents not only keep indefinitely but lend themselves to bulk preparation and standardization in a central issuing laboratory. In this way, uniform results of great value in epidemiological work could be obtained by peripheral laboratories scattered over a very wide area.

The acceptance of a new laboratory test is greatly assisted if the results of the old and the new are simply related. The relation between the indirect fluorescent antibody technique and dye test titres could not be simpler and it is hoped that it will play some small part in hastening the adoption of this elegant and reliable method.

I should like to thank Drs. J. K. A. Beverley and C. N. Iland for letting me have mice infected with the RH strains of Toxoplasma gondii and Dr. G. B. Ludlam who performed the dye tests. I am also grateful to Professor P. C. C. Garnham who made available preparations of trypanosoma, leishmania, and plasmodium, to Drs. N. R. Grist and R. J. Fallon for supplies of sera, and to Dr. H. E. Hutchison for carrying out the Coombs titration.

\section{REFERENCES}

Beverley, J. K. A., and Beattie, C. P. (1952). J. clin. Path., 5, 350 Boorman, K. E., and Dodds, B. E. (1957). Blood Group Serology, p. 81. Churchill, London.

Eichenwald, H. F. (1956). Ann. N. Y. Acad. Sci., 64, 207.

Goldman, M. (1957). J. exp. Med., 105, 549.

Jacobs, L., and Cook, M. K. (1954). Amer. J. trop. Med. Hyg., 3, 860.

Kelen, A. E., Ayllon-Leindl, L., and Labzoffsky, N. A. (1962). Canad. J. Microbiol., 8, 545 .

Ludlam, G. B. (1960). Proc. roy. Soc. Med., 53, 113.

Mandras, A., Vanini, G. C., and Ciarlini, E. (1962). Igiene mod., $55,636$.

Nairn, R. C. (1962). Fluorescent Protein Tracing. Livingstone, Edinburgh.

Proom, H. (1943). J. Path. Bact., 55, 419.

Sabin, A. B. (1949). Pediatrics, 4, 443.

$\longrightarrow$, and Feldman, H. A. (1948). Science, 108, 660.

Stansfeld, A. G. (1961). J. clin. Path., 14, 565.

Warren, J., and Sabin, A. B. (1942). Proc. Soc. exp. Biol. (N.Y.), 51,11 .

Young, M. R. (1961). Quart. J. micr. Sci., 102, 3rd series, 419. 